\title{
Online Consumer Purchasing Behaviour in Slovakia
}

\author{
Dominik Laitkep ${ }^{1}$, Edgars Červkovskis² \\ ${ }^{1}$ Department of Communications, University of Žilina, Žilina,010 26, Slovakia \\ ${ }^{2}$ Department of Business, Europe Distance Education Secondary School, Riga, LV-1019, Latvia
}

\begin{abstract}
The paper describes buying behaviour of Slovak consumers who use social networks. Knowledge of consumer behaviour and consumer preferences means a competitive advantage in the business environment, which is a complex process with many variables. The aim of this study is to present the results of the author's primary research, processed by reducing the number of variables by applying factor analysis. Research shows that consumers are used to making decisions about their purchases directly on the Internet and they using all available information. For Slovak consumers are online order payment together with free delivery important factor for making a purchase in the Slovak e-commerce environment. Another key factor for making purchases are impulses from social networks and the option to purchase through the mobile app.
\end{abstract}

Keywords Purchasing behaviour, E-commerce, Factor analysis, Social networks, Slovak consumers

JEL M39, L81, R19

\section{Introduction}

Consumer buying behaviour includes behaviour of individuals as well as households. Consumers make decisions whether or not to buy on a daily basis while responding to different incentives. These incentives include product, price, method of acquisition as well as various marketing elements such as advertising and various discounts. Based on these incentives, consumers decide where and what to buy and due to satisfy their needs.

Philip Kotler, defines customer needs as state of felt deprivation of some basic satisfaction. Consumer behaviour can be determined by Kulčáková M. and K. Richter as consumers behaviour when purchasing, using, searching for and evaluating products and services when they expect to meet their needs. [2] [3]

On the other side of needs stand enterprises, which one of the strategic objectives is to generate profit. We know several objectives, which are the basis for evaluating the business and measure for success or failure. "Goals are for management and other management level commitment to achieving concrete results at a particular time." [1] If a company is unable to set goals correctly, then it is unable to develop a strategy. In order to meet these goals, businesses today mainly use online marketing communication tools along with social networks.

According to the authors Králiček and Král' we understand marketing communication particularly as promoting business for specific target groups, which fulfils not only marketing but also strategic goals.[4] Another definition regards marketing communication as a influencing protentional customer purchase. [5]
If marketing communication and various supporting attributes are correctly applied, it means premise to improve the market position with increase of enterprise revenue and profit.

\section{Analysis of current state}

We focused on areas of social networks, the basic attributes of marketing communications, as well as the possibility of payment for goods and services, but also a new trend, which are influencers.

Smith defines the social network as an association of communities or groups of people who share a common interests. [7] Social networks popularity these days also brought opportunities for enterprises as affecting users in their communication and decision-making.

Users of social networks are learning from each other, participating in various discussions and they are exposed to various influences by ads which are affected in the process of purchasing. [8]

\subsection{Attributes influencing shopping behaviour}

Marketing communication, through promotional tools like social networks provides information and convincing bases for target consumers. It works as a "stimulus" that can trigger the decision-making process of buying and also helps to make more informed decisions for consumers. It is important to note that marketing communications through online promotion tools are just one of the attributes. [9]

One of the newest attributes are influencers on social networks. Influencers represent a new type of popular people, who form the attitudes of the audience and their followers through blogs, status and other forms of promotion on social networks. [6]

Popular social networks from promotional tools include: 
- Facebook and Instagram - With nearly 2.3 billion active monthly users, Facebook is one of the most important platforms;

- Twitter - With 326 million active users each month, Twitter is almost impossible for companies to ignore, and most of the businesses are active in it;

- LinkedIn - LinkedIn is a social media platform, exclusively for business;

- Newsletter - Email promotion is still the number one of online communication tool;

- Website - The site's role is to provide the necessary information instantly and effortlessly. [12]

By combining different tools of communication through are enterprises promoted, they can gain the best position in the market. By adding various payment options and also providing different forms of transport of purchases, it gives enterprises the opportunity to move closer to their customers wishes. [10]

The e-commerce market also contains other attributes that we have included in our research and can be seen in Table 1.

Table 1. Attributes from primary research

\begin{tabular}{|c|c|}
\hline Number & Attributes \\
\hline 1. & Importance of social networks \\
\hline 2. & The quality of the content on social networks \\
\hline 3. & Truthfulness of the social network content \\
\hline 4. & The importance of influencers \\
\hline 5. & Influencer's option \\
\hline 6. & Promo codes form influencers \\
\hline 7. & Sales actions \\
\hline 8. & Promo codes for first purchase \\
\hline 9. & Companies activities on social networks \\
\hline 10. & Purchasing in store \\
\hline 11. & Online purchasing \\
\hline 12. & Website design \\
\hline 13. & Impulsive shopping \\
\hline 14. & Delivery methods \\
\hline 15. & Free delivery \\
\hline 16. & Offline advertising \\
\hline 17. & Purchase through apps \\
\hline 18. & Suinstable business \\
\hline 19. & YouTube business activities \\
\hline 20. & Business reviews \\
\hline 21. & Purchasing in known company \\
\hline 22. & Cash payment \\
\hline 23. & Online payment \\
\hline 24. & Crypto payment \\
\hline 25. & Newsletter \\
\hline
\end{tabular}

The table show attributes covering areas such social networks, sales promotions and online and offline advertising. attributes influence the purchasing behaviour of customers in the Slovak Republic the most. To achieve this goal, it was necessary to use methods such as the method of excerpting, the method of analysis, primary research, factor analysis, the method of induction and deduction. In conducting the primary survey, we managed to reach up to 1814 respondents, social network users aged 15 to 64 years. Questions from primary survey are the attributes contained in Table 1 . The survey was conducted at the end of 2019 in November. To calculate the minimum sample size, it was necessary to find out how many people in the SR have a target age. At the date of 01 . 07. 2019, the population over 15 years to 64 old in the Slovak Republic is 3,662,779. [11] After finding the number of residents, we used the following formula for the calculation of the basic files:

$$
n \geq t_{1-\frac{\alpha^{2}}{2}} * \frac{\sigma^{2}}{\Delta^{2}}
$$

where:

$\mathrm{n}$ - is the minimum sample size (minimum number of respondents),

t_(1- $\alpha / 2)$ - s the critical value determined from the tables (critical values of the normalized normal distribution),

$\sigma 2$ - is the spread calculated from the standard deviation, $\Delta$ - is the maximum allowable margin of error.

Then we put the values into the formula:

$$
n \geq \frac{1,96^{2}}{0,03^{2}} \times 0,5^{2}=1067,11 \doteq 1068 \text { respondents }
$$

After substituting the values into the formula for the large sample population calculation, we found that at a $95 \%$ confidence level and a 3\% error margin, the minimum sample size was 1068 respondents. We fulfil our sample with 1814 respondents. After fulfilling our sample we used factor analysis to evaluate the results of the primary research, where eight factors were identified. Factor analysis was realized on the platform of opensource software solution PSPP. [13]

\section{Results}

Based on the results from PSPP software presented in the rotated factor matrix shown in Figure 1, it is possible to interpret the outputs. For better interpretation it is necessary to understand the rotation of factors. After the rotation is applied, it is possible to identify the correlation values for the individual factors and define them, so that the load of that factor can be identified by the relevant variable. The values of the correlation coefficient reaches a value ranging from 1 to $+1,-1$ which is the most possible negative correlation and +1 highest positive correlation. A value of 0 represents a zero correlation.

\section{Methodology}

The aim of the article was to identify individual attributes and subsequently to determine the extent to which of these 
In this case we proceed by sorting the relevant variables to the factors by assigning them to the factor by their highest value. The given rotational matrix shows the relationships between the variables. The factor matrix represents a matrix of identified factors and correlation values between identified factors 1 to 8 . This is the main output of the factor analysis.

\begin{tabular}{|c|c|c|c|c|c|c|c|c|}
\hline \multicolumn{9}{|c|}{ Rotated Component Matrix } \\
\hline \multirow{2}{*}{ Atributes } & \multicolumn{8}{|c|}{ Component } \\
\hline & 1 & 2 & 3 & 4 & 5 & 6 & 7 & 8 \\
\hline \multirow{2}{*}{$\begin{array}{l}\text { 1. The importance of social networks } \\
\text { 2. The quality of the content on social networks }\end{array}$} & .07 &, 04 &,- 01 & .26 & .17 & .71 & ,03 & .15 \\
\hline & .05 & .13 &.,- 02 & .20 & .27 & .75 & .01 & 0,6 \\
\hline \multirow{3}{*}{$\begin{array}{l}\text { 3. Truthfulness of the social network content } \\
\text { 4. The importance of influencers } \\
\text { 5. Influencer's opinion }\end{array}$} &,- 06 & .25 & .05 & .00 &., 07 & .62 &., 02 & .00 \\
\hline & .30 &, 04 &, 04 & .03 & .84 & .09 &, 00 &, 09 \\
\hline & .27 & , 08 & ,03 & .12 & .46 & .20 & .00 & .75 \\
\hline 6. Promo codes from influencers & .16 &, 06 & .02 & .40 & .54 & .21 & .03 & .22 \\
\hline \multirow{3}{*}{$\begin{array}{l}\text { 7. Sales actions } \\
\text { 8. Promo codes for first purchase } \\
\text { 9. Companies activities on social networks }\end{array}$} & .04 & .11 &., 02 & .78 & .11 &, 04 & .05 & ,03 \\
\hline & .17 & .16 & .00 & .65 & .04 & .20 & .06 & .02 \\
\hline &, 19 &, 09 &,--01 & .64 & .01 & .20 &, 00 &, 01 \\
\hline 10. Purchasing in store &, 14 &,- 05 & .92 &,- 03 &,- 02 &, 04 &,- 12 &, 00 \\
\hline 11. Online purchasing &,- 05 & .15 & -.51 & .19 & .06 & .04 & .75 & .02 \\
\hline 12. Website design &, 11 & .49 & -.22 &,- 04 & .08 & .21 & ,14 &, 04 \\
\hline 13. Impulsive shopping & 31 &, 03 &,- 19 &., 33 & .37 &, 00 &., 12 &, 23 \\
\hline \multirow{2}{*}{$\begin{array}{l}\text { 14. Delivery methods } \\
\text { 15. Free delivery }\end{array}$} &,- 13 & .60 &.,- 01 & .15 &., 08 & .11 & .03 &., 04 \\
\hline &,- 03 & .48 &, 10 & .26 & ,08 &,- 11 &,- 04 &, 06 \\
\hline 16. Omline advertising & .54 &, 02 & .20 & ,17 &, 05 & ,08 &,- 14 &, 00 \\
\hline 17. Purchase through apps & .27 & .09 & -.22 & .15 &.,- 16 & .40 & .14 & -.14 \\
\hline 18. Sustainable business & .49 & .24 &, 00 &,- 24 &,- 15 & .24 & ,03 &,- 08 \\
\hline \multirow{2}{*}{$\begin{array}{l}\text { 19. YouTube business activities } \\
\text { 20. Businesses reviews }\end{array}$} & .58 & .11 &,- 01 & .07 & .22 & .09 & .05 & .10 \\
\hline & ,08 & .62 & -.07 & -.04 &., 04 & .21 & ,04 &,- 01 \\
\hline $\begin{array}{l}\text { 20. Businesses reviews } \\
\text { 21. Purchasing in known company }\end{array}$ & .06 & .63 & .04 & .07 &, 06 &, 11 &, 03 &, 04 \\
\hline \multirow{2}{*}{$\begin{array}{l}\text { 22. Cash payment } \\
\text { 23. Online payment }\end{array}$} & .05 & .35 & .35 & .10 & ,08 & -.07 & -19 &, 03 \\
\hline & .18 & .24 & -.22 & .14 & -.22 & .17 &, 15 &,- 12 \\
\hline \multirow{2}{*}{$\begin{array}{l}\text { 24. Crypto payment } \\
\text { 25. Newsletter }\end{array}$} & .58 &,- 14 & -05 &., 11 &, 16 &,- 17 & ,04 &, 10 \\
\hline & .58 &,- 03 & \begin{tabular}{|l|l|l|}
, 06 & \\
\end{tabular} & .33 & .16 & .02 & $\begin{aligned}-, 01 \\
\end{aligned}$ &, 05 \\
\hline
\end{tabular}

Figure 1. Output from PSPP software - Rotated component matrix.

In the case of variable number 22 we assign the variable to factor number 3 as it achieves the same value in factor 2 but due to the nature of the question it is more inclined to include factor 3 .

\subsection{Factors reduction}

Based on the results presented in the rotated factor matrix, it is possible to interpret the outputs. It can be stated that all variables affect respondents when buying, each of which has a different importance. We found that the dependence between attribute variables can be characterized by reducing variables to eight factors. All attribute variables positively correlate with factors.

\subsubsection{Factor No. 1.}

Factor number 1 contains variables whose acquired value is from 0.49 to 0.58 . Factor No. 1 represents a combination of variables such as offline advertising together with YouTube activities and the existence of newsletters advertising and crypto paying.

\subsubsection{Factor No. 2.}

Factor number 2 contains variables whose acquired value is from 0.49 to 0.63 . Factor No. 2 represents a combination of variables such as online payment, delivery methods, business reviews and website design. Based on the results of determination of signification value shown in table number 2., it can be confirmed that this is a minor factor affecting the customer when they making a purchase.

\subsubsection{Factor No. 3.}

Factor number 3 contains variables whose acquired value is from 0.35 to 0.92 .. Factor No. 3 represents a combination of variables such as purchasing in store together with cash payment.

\subsubsection{Factor No. 4.}

Factor number 4 contains variables whose acquired value is from 0.64 to 0.78 . Factor No. 4 represents a combination of variables such as sale actions together with promo codes for first purchase and the existence of company activities on social networks.

\subsubsection{Factor No. 5.}

Factor number 5 contains variables whose acquired value is from 0.37 to 0.84 . Factor No. 5 represents a combination of variables such as impulsive shopping together with impulses for purchasing from influencers.

\subsubsection{Factor No. 6.}

Factor number 6 contains variables whose acquired value is from 0.40 to 0.75 . Factor No. 6 represents a combination of variables such as using of importance of social networks together with purchasing through apps.

\subsubsection{Factor No. 7 and No. 8}

Factor number 7 contains only one variable which acquired value is 0.75 . Factor No. 7 represents online purchasing variable.

Factor number 8 contains only one variable which acquired value is 0.75 . Factor No. 8 represents Influencers opinion variable.

\subsection{Determination of signification value}

For transformed factors 1 to 8 , a significance value was determined which evokes the importance of influencing them in the purchase. The most important is the one with highest value.

Table 2. Determination of signification value

\begin{tabular}{|c|c|c|}
\hline Serial No. & Factor & Significance value \\
\hline 1. & No. 2 & {$[(3,54+4,1+3,67+3,85+3,60+3,70) / 6]=\mathbf{3 , 7 4}$} \\
\hline 2. & No. 6 & {$[(3,15+3,18+4,24+3,33) / 4]=\mathbf{3 , 4 7}$} \\
\hline 3. & No. 3 & {$[(3,05+3,34) / 2]=\mathbf{3 , 2 2}$} \\
\hline 4. & No. 7 & {$[(3,19) / 1]=\mathbf{3 , 1 9}$} \\
\hline 5. & No. 4 & {$[(2,76+2,78+2,78) / 3]=\mathbf{2 , 7 7}$} \\
\hline 6. & No. 1 & {$[(2,29+3,40+2,06+1,41+1,96) / 5]=\mathbf{2 , 2 2}$} \\
\hline 7. & No. 8 & {$[(2,03) / 1]=\mathbf{2 , 0 3}$} \\
\hline 8. & No. 5 & {$[(1,76+2,34+1,73) / 3]=\mathbf{1 , 9 6}$} \\
\hline
\end{tabular}

The table number 2 . shows the significance values of these factors. The determination of materiality was based on the average values determined using the liquor scale in the realized primary survey. 


\section{Conclusions}

Based on the presented research and the results of the factor analysis, it is possible to express that the purchasing behaviour of Slovak customers which are using social networks is influenced mainly by traditional and already used tools.

These tools are a design website, delivering methods with an ordering for free along with online payment. Reviews of online businesses and shopping from well-known businesses are also important. This result proves that, online communication tools are still have the greatest impact on the buying behaviour of customers. For customers are also important social networks and truthfulness of published posts.

For enterprises, it is very important to use all tools and the opportunities that the Internet provides. The results reveal interesting findings in relation to the mutual correlation between the examined variables. The results also reveal their significance in terms of their impact on customer purchasing behaviour and the achievement of the enterprises on the turbulent market.

\section{REFERENCES}

[1] SLÁVIK, ̌. 2005. Strategický manažment. Bratislava: SPRINT, 2005. 403 s. ISBN 80-89085-49-0. s. 48.

[2] KOTLER, Ph.: Marketing management. Praha : Grada Publishing, 1998. 710 s. ISBN 80-7169-600-5.

[3] KULČÁKOVÁ,M., RICHTEROVÁ, K.: Spotrebitel'ské správanie (Vybrané kapitoly). Bratislava : Ekonóm. 1996, s. 6.

[4] KARLÍČEK, M., KRÁL, P. Marketingová komunikace: jak komunikovat na našem trhu. 1. vyd. Praha: Grada, 2011, 213 s. ISBN 978-80-247-3541-2.
[5] HESKOVÁ, M., ŠTARCHOŇ, P. Marketingová komunikace a moderní trendy v marketingu. 1. vyd. Praha: Oeconomica, 2009, 180 s. ISBN 978-80-245-1520-5.

[6] Gorry, G. A., \& Westbrook, R. A. (2009). Winning the internet confidence game. Corporate Reputation Review, 12(3), 195-203.

[7] SMITH, A. N., FISCHER, E., YONGJIAN, CH. How Does Brand-related User-generated Content Differ across YouTube, Facebook, and Twitter?. Journal of Interactive Marketing [online]. 2012, vol. 26, issue 2, s. 102-113

[8] SABATE, F., BERBEGAL-MIRABENT, J., CAÑABATE, A., LEBHERZ, R. Factors influencing popularity of branded content in Facebook fan pages. European Management Journal [online]. 2014, vol. 32, issue 6, s. 1001-1011

[9] LI, Y., LAI, CH., CHEN, CH. Identifying bloggers with marketing influence in the blogosphere. In: Proceedings of the 11th International Conference on Electronic Commerce ICEC '09 โonline]. New York, New York, USA: ACM Press, 2009, s. 335, ISBN 9781605585864.

[10] Belch, G. E., \& Belch, M. A. (2011). Advertising and Promotion: An Integrated Marketing Communications Perspective (9th ed.). McGraw-Hill Education.

[11] Vekové zloženie - SR, oblasti, kraje, okresy, mesto, vidiek. (2020). STATdat.

[12] Search engine journal - The 7 Biggest Social Media Sites in 2020. Avaible: <https://www.searchenginejournal.com/social-media/biggest-social-media-sites/\#close >.

[13] Statistika PSPP. Dostupné na internete: < https://statistikapspp.sk/softver-pspp/>. 